\title{
液々透過膜の性能評価法
}

\author{
山田純 男 \\ 製品科学研究所 $\bar{T} 305$ 茨城県筑波郡谷田部町東 1-1-4
}

\section{Evaluation of Pervaporation Membrane for Separation \\ of Liquid-liquid Mixture}

\author{
Sumio Yamada \\ Industrial Products Research Institute, Yatabe-machi, Tsukuba-Gun, Ibaraki 305
}

\begin{abstract}
Pervaporation process which is a useful membrane separation technique for wide varieties of organic liquid mixtures has recently been noted. This method can be expected to be useful particularly for separation of close-boiling mixtures, azeotropic mixtures and others. Since the criteria in membrane separation process is to develop excellent membrane, we must properly evaluate the membrane functionality such as selectivity and durability. In this chapter, pervaporation apparatus, operation procedures, presentation of experiment data, problems in measurement, factors affecting separation and mathematical treatment were described.
\end{abstract}

\section{1. はじめに}

炭化水素類などの有機液体混合物から目的とする有機 液体を分離し, 取除いたり, また微量成分を濃縮し, 精 製する場合に利用される膜分離技術がいわゆるパーベー パレーション分離法といわれるものである. 原理的には 極めて簡単で, その原理図を Fig. 1 に示したが, 分離 膜の一方の側に混合液体を置き，他方は透過物質を取り 除くために真空にしたり, carrier gas を流す方式で, 膜 を透過する際に透過速度の違いにより分離が行われる。

この膜分離法は初め, この分野で先駆的な仕事をした Binning によって Liquid Permeation (液透過法) と呼 ばれまた Choo は Membrane Permeation というよ うに命名していたが，その後この分離法の過程が，(1)液 の浸透する部分 (Fig. 1 の膨潤層) と, (2)蒸気として蒝 発, 気化する部分 (緻密層) の二つの step から成って いることが明らかにされ， pervaporation というように 呼ばれるようになった。この pervaporation は permeation (透過あるいは浸透) と evaporation (蒸発, 気化) の合成語なので浸透気化 (蒸発) 法と訳している人もい る.

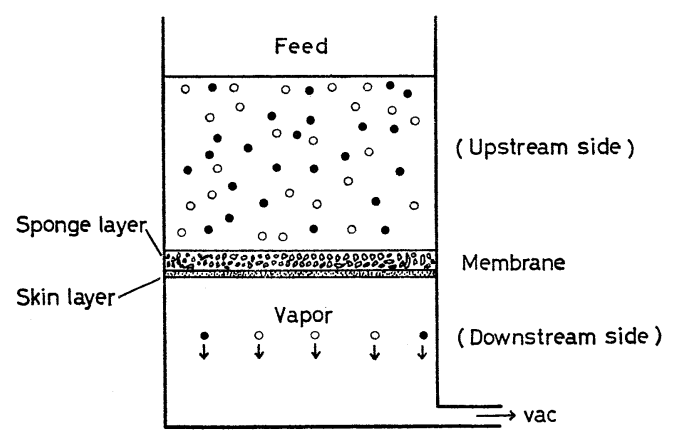

Fig. 1 Principle of pervaporation.

パーベーパレーション分離法は古くからタンパク質溶 液を半透膜の袋に入れ, 空気中につるして, 水分を蒝発 させて濃縮する方法などに用いられていたが，実際面で 本格的に研究され始めたのは，1950年代でありまだ30年 の歴史しかない若い技術である. Kahlenberg1)は早くも 1906年に，ゴ膜を使って炭化水素とアルコールの分離 を定性的ながら研究している。最初の定量的な研究は Hagerbaumer $^{2)}$ が 1955 年に microporous な Vycor ガ ラス板で, 高圧下の特に共沸混合物について, 有機液体 
混合物の分離を行なったのが初めてであろう．とこで初 めてこの方法が工業上の一操作として応用できることが 示唆されたわけである。爷の後 Heisler3) が1956年に， 有名な Binning ら4)は1958 年に有機均質膜で,この hybrid な分離法の可能性を検討した. American Oil 社 の Binning らの研究は非常に広い範囲にわたるもので, 満足のいく高い分離率と透過速度を一応得ることができ た.これより少し遅れて MITの Michaels ら5)の優れ た研究成果が出され, 彼らは新しい液分離法の概念を提 案している. Michaels 門下の Choo がその後を引き受 け，60 年代の中頃には pervaporation は工業化段階に 移ったことを発表し，コストの試算も行われている6). しかしその後実際プラントは動いていない上うである。 何故このように原理的に長所をもちながら最終的に受け 入れられなかったかは，一つには従来の蒸留法等の既存 の設備がありながら, 改めて設けるにはめまりにも設備 投資の費用が高くつくこと, 一つ一つの単位操作設備を つくることの難しさと, 膜の分離性能も含めた耐久性に 問題があったのではないかと推測される．この他60年代 には Esso 社の Long や Li らもパーベーパレーショ ン法と蒸気透過法とが極限条件では同一になることを実 験的に立証するなどいくつかの貢献をしている7．70 年 代に入ると, Cabasso8), Aptel ら9) と McCandless10) は ブレンドマー，グラフトあるいは配合などの方法によっ て目的の分離機能構造をもたせた新しい膜の材料設計を 行い, 沸点近接化合物, 共沸混合物あるいは構造異性体 の液分離を手がけ，注目すべき成果を得ている。

膜分離法にあってはその価值を決定するものはなんと いっても膜の分離性能であうう。そこで正しい膜の性能 評価ということが非常に大切なことになるが，ここでは パーベーパレーション分離法に打ける分離膜の性能評価 といらことから, 測定装置, 実験操作法, データの表示 法, 測定上の問題点, 測定に影響する因子と多少の数学 的取扱いについて述べたい，最近パーベーパレーション 分離法についての総説もいくつか出されるようになって きているのでそれらも参照されたい,6,11 13).

\section{2. パーベーパレーションの概念}

この pervaporation 技術は冒頭に述べたように有機液 体混合物の分離精製を目的とするもので, 従来行われて きた分離技術の蒸留, 再結晶, 溶媒抽出, クロマトグラ フィなぞと競合する宿命をもつ膜分離技術の一つという ことができる.

Fig. 2 には 1 例として水-プロピルアルコールの分離

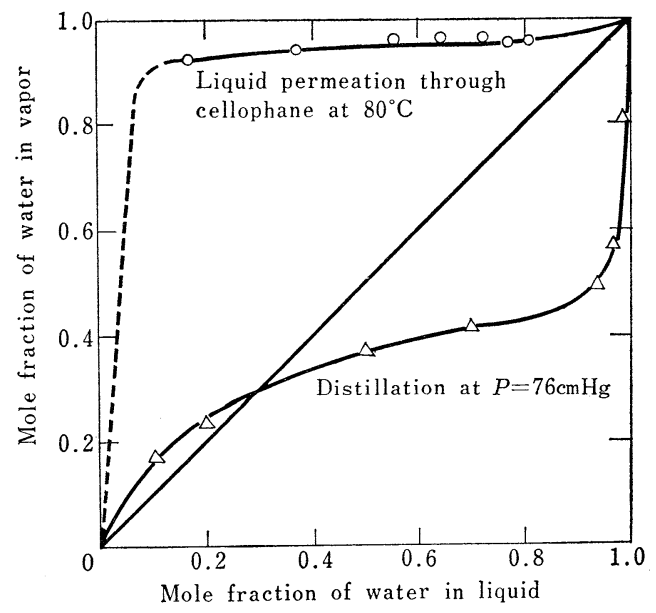

Fig. 211) Comparative separation of water-isopropanol mixtures by distillation and pervaporation.

Table 1 膜分離法の位置づけ

\begin{tabular}{|c|c|c|c|}
\hline$\left(\begin{array}{l}\text { 高濃 } \\
\text { 度側 }\end{array}\right)$ & (膜) & $\left(\begin{array}{l}\text { 低濃 } \\
\text { 度側 }\end{array}\right)$ & 分離法めるいは現象 \\
\hline 気体 & - & 気体 & 気体めるいは蒸気透過法 \\
\hline 気体 & - & 液体 & $\begin{aligned}: & \text { 膜型人工肺, 膜センサー, 液 } \\
& \text { 体のパウチ包装の酸化防止 }\end{aligned}$ \\
\hline 気体 & - & 固体 & $\begin{array}{l}: \quad \text { ビニル鋼板の防蝕, 膜センサ } \\
\quad-\end{array}$ \\
\hline 液体 & - & 気体 & $\begin{array}{l}: \quad \text { パーベーパレーション法（液 } \\
\text { 透過法） }\end{array}$ \\
\hline 液体 & - & 液体 & $\begin{array}{l}\text { : 透析法, 逆浸透法, 限外沪過 } \\
\text { 法, Perstraction (浸透抽出法) }\end{array}$ \\
\hline 液体 & - & 固体 & $\begin{array}{l}\text { イオン交換膜法, 膜センサー } \\
\text { : 化学修飾電極 }\end{array}$ \\
\hline
\end{tabular}

を蒸留法と液透過法とによって行った比較を示した ${ }^{11)}$. ワンステップの操作で比較すると液透過法がいかに優れ ているかがわかる。

次にパーベーパレーション分離法が, 膜分離法のなか でぞのような位置を占めるのかを考党てみよう，膜分離 法を一般的に考觉る場合, 膜によって二つの相がへだて られている訳であるから，この相の組合せによって Table 1 のような分類が考兄られる.ここで組合せとして 高濃度側を固体とする三つの組合せが考学られるが，流 速の面から現実的でないので除外した。 また膜としては 固体膜だけを考えた，その他荷電も考慮するとさらに事 


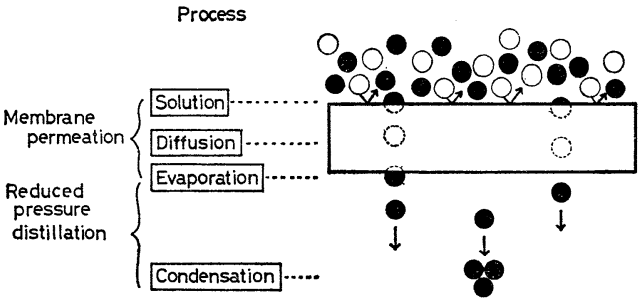

Fig. 3 Analysis of separation function from the direction of membrane cross section.

例が多くなるが，これも省いた，事例のなかには膜分離 法として該当するものがないので, 膜透過現象をとりあ げているものも含まれるが, Table 1 から, 要するにパ 一ベーパレーションは液体一膜-気体の系の唯一の膜分離 法だということができる。

しかし実際面で考劣てみると，パーベーパレーション 分離法というのは, 逆浸透法と蒸気膜分離法の合いの子 に当るようなものである. 確かに蒸気透過法では分離す る対象が水蒸気とか有機蒸気であることが違うのであっ て，透過してくる側を減圧にしていることでは液透過法 と同じである。しかも相詨蒸気圧が 1 のとき活動度の 考え方から液と同一になってくるので，この場合どちら の方法であるのか一線を画しがたくなる．活動度は別に して同一条件で両者を比較した場合，パーベーパレーシ ョン法の方が透過速度が速いという実験結果が報告され ている4). 一方逆浸透の側面から眺めれば, 逆浸透の場 合低圧側の膜面は液で濡れているが，これを素早く取り 除くように，すなわち素早く気化させるようにすれば， 液透過分離法の技術ということになる。 また実際逆浸透 法で圧力を無限大にもっていったとき，パーベーパレー ションの透過速度の結果と一致することが実験的にも理 論的にも証明されている14).

ここで他の膜分離法の機能と比較するために, 液透過 法の分離機能を膜の断面方向から観念的に考察し, 模式 的に図示したのが Fig. 3 である。液透過法では透過液 が膜面でまず溶解し, 膜中を昖散, 浸透し, 反対側の膜 面で蒸発, 気化が行われ, それから冷却, 凝縮と続いて 捕集される工程とつながる，先に述べたように液透過法 はある面では蒸気透過とよく似ている，しかし透過分離 プロセスとして考立た場合非常に異なっている，蒸気透 過では透過分子が膜を透過し，分離されるまでのプロセ スを考えてみると，蒸気と接している膜面でまず溶解し， 膜中を挔散，膜を出たところで脱着するという段階を経 て終了する。したがって蒸気透過では, 液透過法の前半

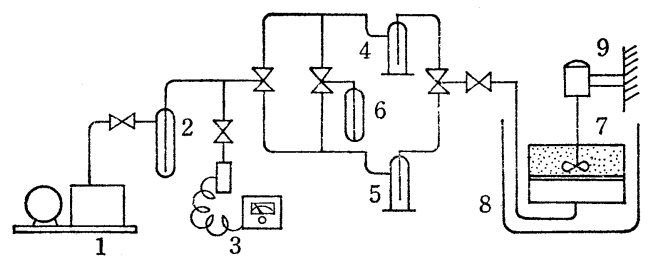

Fig. 415) Diagram of the liquid permeation apparatus.

1, vacuum pump; 2, cold trap; 3, pirani gauge; 4,5 , cold traps for collecting liquid; 6 , drying tube for vent; 7 , pervaporation cell; 8 , constant temperature bath; 9 , stirring motor; $\triangleright \triangleleft$, stopcock.

のプロセスだけしか使っていないことになる．よく考え てみると後半のプロセスは減圧分別蒸留の時のステップ と同じであるから．この液透過法には潜在的に膜透過と 分別蒸留の工程が組合わさったプロセスであると見なす ことができる．言換えれば．液透過法は膜を取り去って 考えれば減圧蒸留そのものなのである，もしこの各過程 をうまく使いこなせば今以上に分離機能を向上させるこ とができると期待されるし，全く新しいユニットプロセ スが生まれる可能性もある.

\section{3，パーベーパレーション測定実験と膜性能評価}

\section{1 測定装置, 液透過セルと操作法}

Fig. 4 に通常のパーベーパレーション実験を行うとき の液透過測定装置の代表的な例を眓示した ${ }^{15)}$ ，研究論文 にでている他の液透過測定装置 $6,8,9,10,16)$ にいても大同 小異である. Fig. 4 でまず 7 の液透過セルに試料膜を 装着し, 膜の上側に分離すべき供給液を与えた後, 膜の 低圧側の全系を真空ポンプで排気し, 常時 $10^{-2} \mathrm{mmHg}$ 以下に保つ.このとき液透過セルは恒温水槽につけて一 定温度に保持し，供給液の均一性を維持するために攪拌 器 9 を一定速度で回転させる．3は全系の真空度をモ二 ターするためのピラニー真空計である．測定操作手順と しては，通常膜と供給液が膨潤平衡に到達してから，コ ールドトラップ 4，5を液体窒素で冷却し，低圧側を真 空にし，コールドトラップを交互に切り換えながらバッ チ式に取りはずし，透過液の重量を時間とともに測定し て，定常状態の透過曲線から透過速度 $\left(\mathrm{g} / \mathrm{m}^{2} \cdot \mathrm{hr}\right)$ を求 める. Fig. 4 のなかの 6 は，4，5のコールドトラップを 取りはずすときに使う vent で，2のコールドトラップ は回転ポンプの保護のためのトラップである. Fig. 5 に 


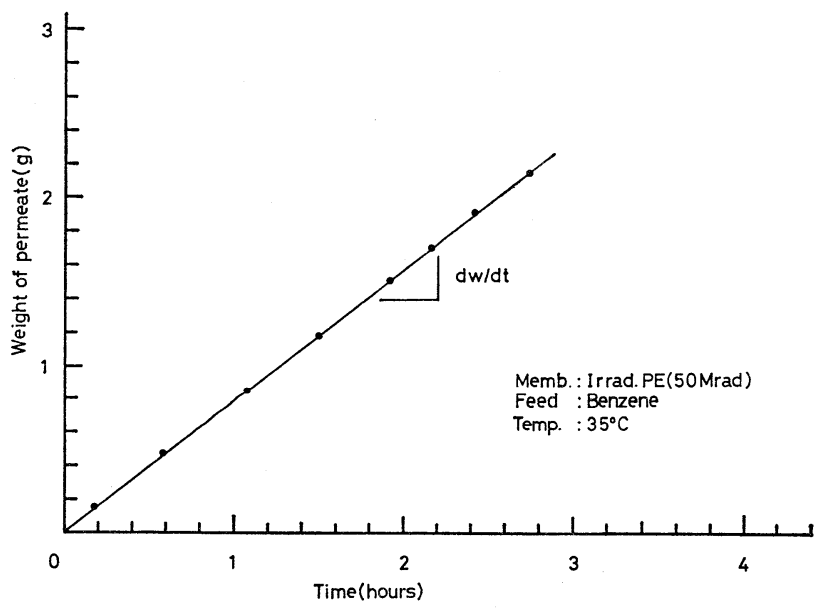

Fig. 5 Permeation curve for benzene through $50 \mathrm{Mrad}$ irradiated polyethylene membrane at $35^{\circ} \mathrm{C}$.

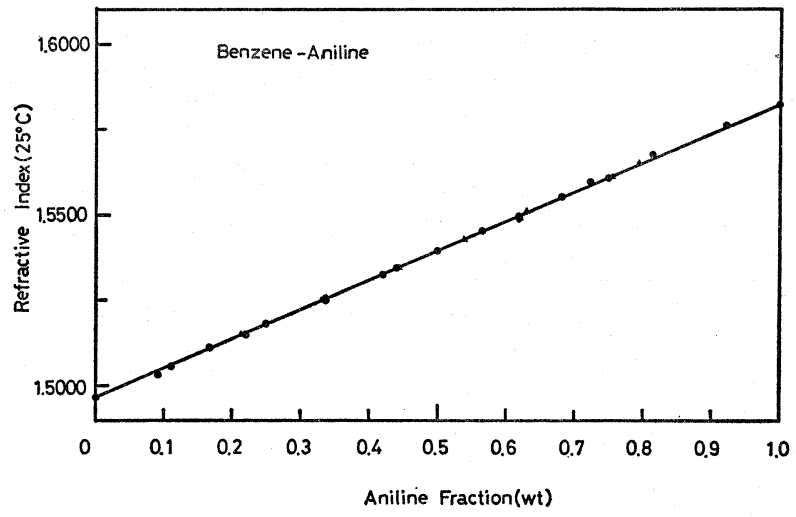

Fig. 6 Calibration curve for benzene-aniline mixture.

典型的な液透過曲線を示した，膜の膨潤平衡後に測った 透過曲線なので, time lag は現われておらず, いきなり きれいな直線を画いている，重量は $0.01 \mathrm{~g}$ をで測れる 精度の電子天科で測った。

一方分離係数は，トラップにたまった透過液を，Abbe 精密屈折計, 液ク口用の U. V., 可視などの検出器, ガ スクロ, 水分計, 精密密度計女るいは電位差滴定装置な どを用いて測定し，透過液の組成を決定して求めた.

Fig. $6 〜 9$ に透過液の組成を決定するときに使った検量 線の代表的な例を示した. Fig. 6 は精密アッべ屈折計で 測ったベンゼンーアニリンの二成分系混合液の $25^{\circ} \mathrm{C} に$ おける屈折率と組成との関係を示した検量線である.

Fig. 6 で黒丸と黑三角のプロットは日を变えて測定した 場合の值で，この例ではきれいな直線にのっているが，
この屈折率と組成の関係も混合系によって必ずしも直線 にはならない.Fig. 7 には同じアッべ屈折計を使って求 めた水ーブチルアミン混合系の検量線の例を示したが, 僅 かに上に凸の曲線になっている。 さらに水一エタノール 混合系の場合では極大值をもつ曲線を示し，したがって この場合ある領域では屈折率から組成が一義的に定まら ない. Fig. 8 は日立ガスクロマトグラフ 063 型でベンゼ ンーアニリン混合系を分析し，帰属ピーク高さの比とベ ンゼンの重量パーセントとの関係を表わしたものである. これから peak height の比がわかれば，混合系の組成が 求まることがわかる．超精密ディジタル密度計 (Anton Paar K. G.) で測った，ブチルアミンー水系の 比重と容 積百分率の関係を Fig. 9 に表わした.

次にわれわれが用いている液透過セルの断面図を Fig. 
34 山田：液々透過膜の性能評価法

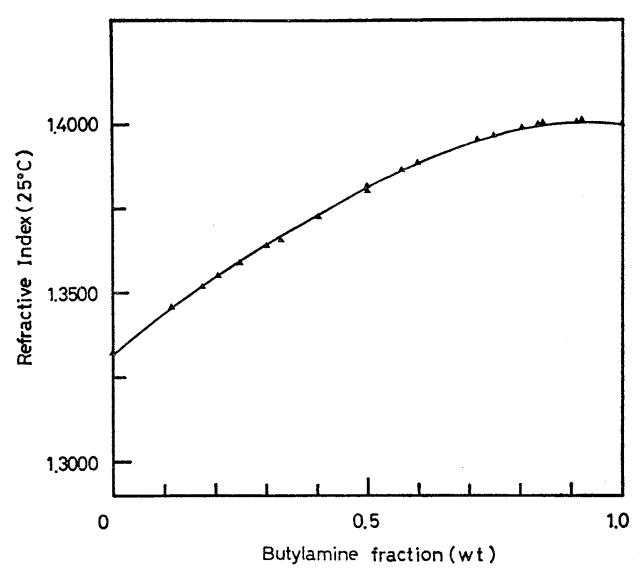

Fig. 7 Calibration curve for $\mathrm{H}_{2} \mathrm{O}$-butylamine mixture.

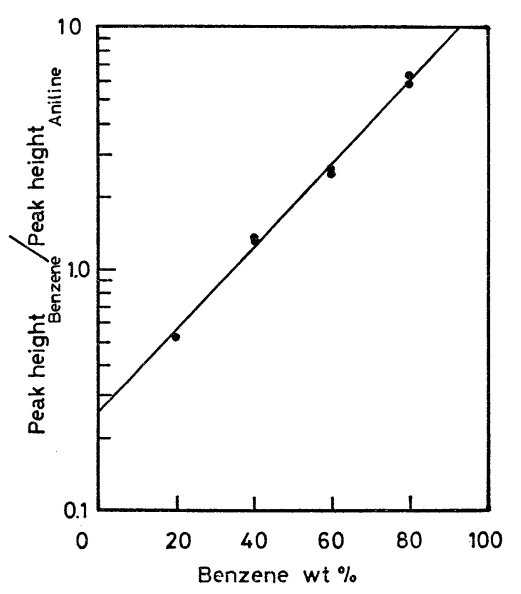

Fig. 8 Calibration curve for benzene-aniline mixture by gas chromatograph

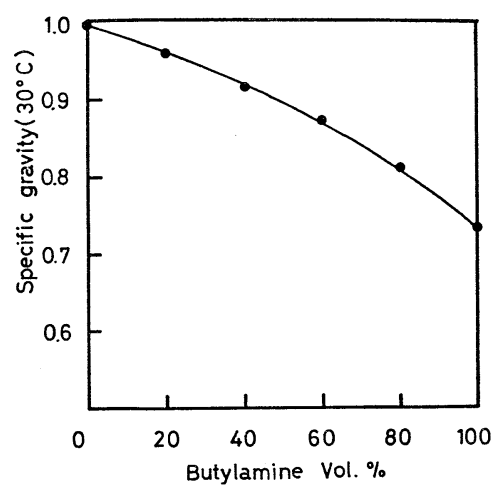

Fig. 9 Specific gravity vs. feed composition (Vol $\%)$ of butylamine-water.

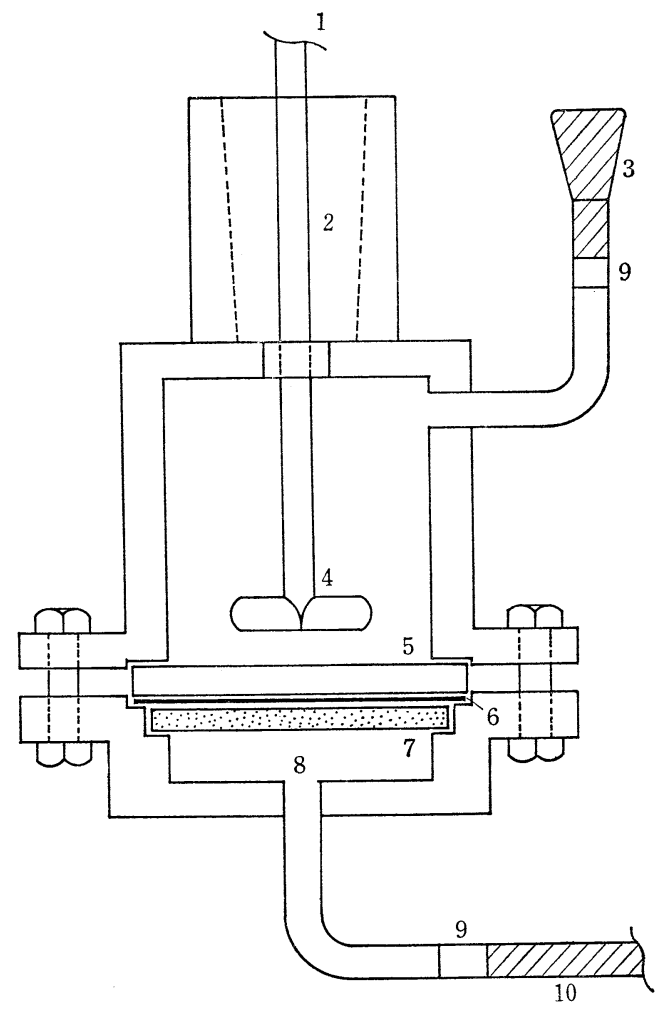

Fig. 1015) Cross section of the pervaporation cell 1, teflon stirrer; 2, "Mighty Seal"; 3, universal ground glass joint; 4, upper compartment; 5, teflon gasket; 6, cross-linked polyethylene membrane; 7, sintered metal disk; 8, lower compartment; 9, koval metal-to-glass connection; 10 , outlet of the lower compartment.

10 に示した ${ }^{15)}$. 液透過セルは供給液として腐蝕性の有 機溶媒を使うためセル全体を耐蝕性のステンレス鋼製と し，ガスケットの部分はテフロン製で，真空系への接続 部分など一部分をガラス製とした。テフロン製スターラ 一のある上室 4 に 3 のところから滴下ロートで供給液を 与え, 上室 4 と下室 8 の間にテフロンガスケットと試料 膜を挿入して，フランジのボルト締めで接合し，10から 真空排気系につないだ.

この外一般的に使われている液透過セルについても原 理的には同じであるが6,8,9,10,16)，それぞれに工夫がこら されている。特に Binning ら4)が初期に考案した液透 過セルは変っている.ちょうど正方形の 5 つの面に膜が 固定できるようになって括り，残りの一つの面から吸引 
用のパイプがでている形のフィルムホルダーを分離すべ き液中に浸けて液透過を行らわけである．占有容積に比 して分離膜の有効面積が多く取れる利点はあるが，実験 室用としては使いらららい。

現在市販されている唯一の液透過セルとしては，加圧 型であるが，Abcor Corp (米国) 製のセルがある. Fig. 11 にその断面の概略を示した ${ }^{17,18)}$. 全体がステンレス スチール製でできて挔り，膜上部にゲージ圧で $50 \mathrm{~atm}$ まで掛けられるようになっている，七ルの内容積は約 $80 \mathrm{ml}$ で，系は二つの O-ring で気密性が保たれるよう になっている．最近われわれは逆浸透圧装置を横型にし たような加圧型液透過セルを設計開発した ${ }^{19)}$.
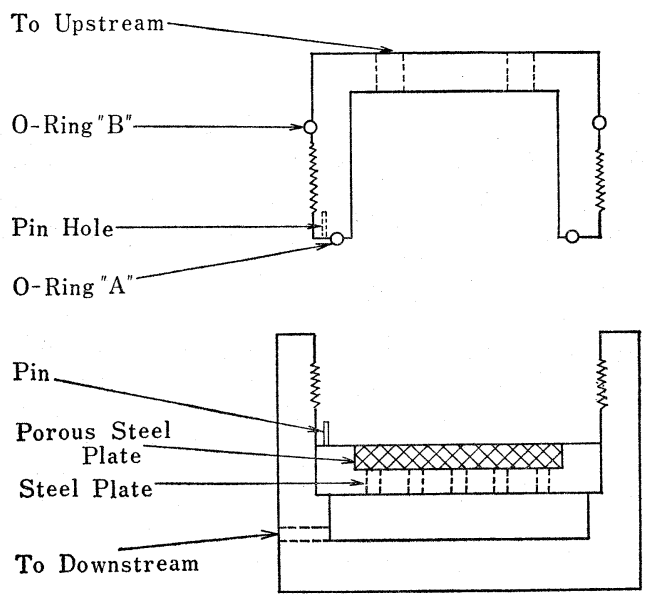

Fig. 1117) Schematic diagram of the permeation cell.
実際の液透過測定装置は Fig. 4 に示したような装置 が複数つながった装置が使われているが，その例として われわれが現在使用している多連型液透過装置の概略図 をFig. 12 に示した. 測定原理としては Fig. 4 と全く 同じである. Fig. 12 では 8 のところに透過量に対応さ せていろいろな大きさのU字型のトラップをつけ，バッ チ式に透過液を調べる，液透過実験の場合は測定時間が 比較的短く，真空ポンプへの切換えが多いため，一つの ポンプで二つのセルを分担させている．Fig. 12 の中で 9 はガスクロその他の検出器の導入口である. 一番右側 の cell は多段トラップ用で，コールドトラップの冷却 レベルを 3 段階に分けて，凝縮の段階で分別を試みよう とするもので离る. Fig. 13 には Greenlaw らが使った 液透過実験装置のブロック図を示した ${ }^{17) .}$

以上述べてきた液透過測定装置はいずれもバッチ式で あるが，ガスクロマトグラフを検出器に使い, 連続式に して自動化しようという動きも見られる20).
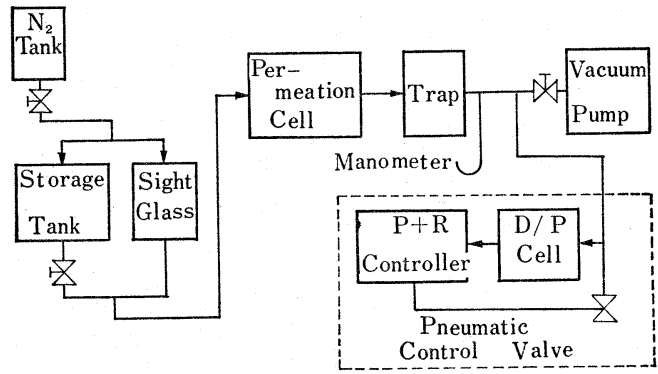

Fig. 1317) Schematic diagram of the experimental apparatus.

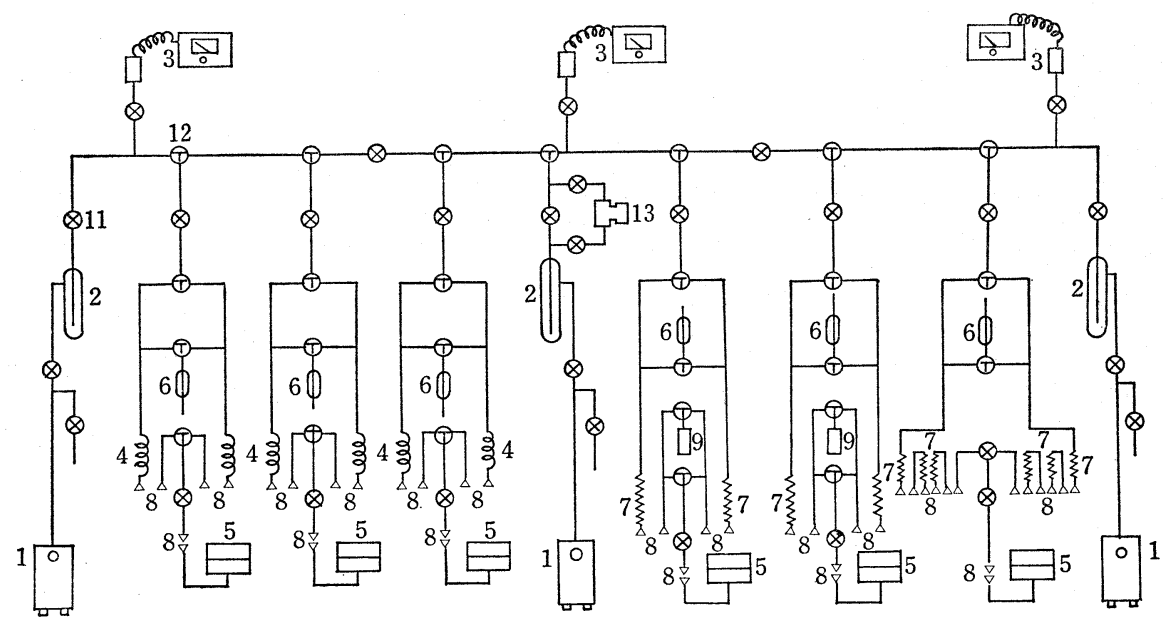

Fig. 12 Pervaporation apparatus 


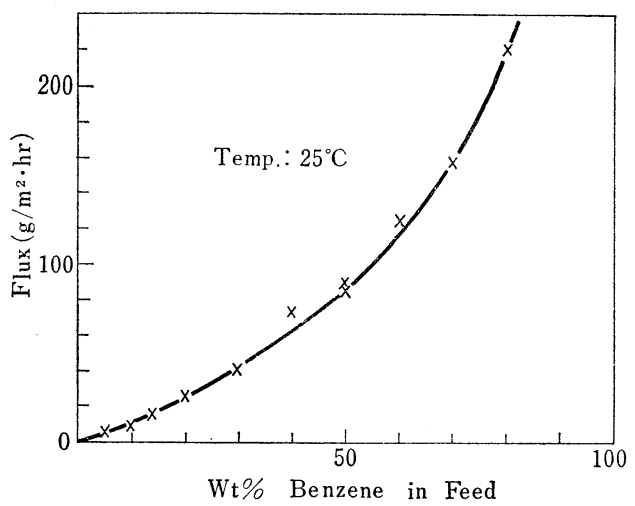

Fig. 1415) Effect of feed composition on the total liquid permeation rate of benzene-aniline mixture at $25^{\circ} \mathrm{C}$.

\section{2 データの表示法と膜性能評価}

次に最も一般的なデータの表現法について述べる.

3.1 でも触れたように液透過実験で測定してでてくる重 要な透過分離パラメータは透過速度と分離係数であるか らまずこれらの数值を表示しなければならない。透過 速度は一般に膜厚が単位のなかに含まれておらず, $\mathrm{g} / \mathrm{m}^{2}$ $\cdot \mathrm{hr}, \mathrm{kg} / \mathrm{m}^{2} \cdot \mathrm{hr}, l / \mathrm{m}^{2} \cdot \mathrm{hr}$ の単位で表わされることが多 い.さらにそれぞれの重さ, 長さ, 時間の単位を変えて 表わされることもある. 透過速度は Fig. 5 で示す透過 曲線から単位時間当りの透過量 $\mathrm{g} / \mathrm{hr}$ をセルの有効透過 面積で割れば簡単に求められる。したがって透過速度の 場合別途膜の厚さを表示しないと意味がない，膜厚さの 違う透過速度を対比するために厚さも考慮した比透過速 度で表わすことがある。これは透過速度と膜厚を掛けた 数值である. 透過速度は混合液系の場合, 供給液中の膜 を膨潤する成分の濃度によって著しく変わるため, 混合 物の供給液の全透過速度として, 通常供給液のある一定 組成比のときの数值を明示するよりも, 透過速度が全濃 度にわたってどのように変化するかを表わした Fig. 14 で示す方がわかりやすい. Fig. 14 は架橋ポリエチレン フィルムでベンゼンーアニリン混合液の 全透過速度を調 ベた結果で15)，横軸には供給液中のベンゼン濃度をとっ ている．次に必要なデータとしては，他の膜透過法と同 じょうに透過速度の温度に対する関係を図示することが 望ましい(Fig. 15).

一方, 分離係数の表示であるが, その前にここで二成分 系の場合の分離係数の定義を述べて置く．分離係数 $(\alpha)$ というのは，供給側（液側）の $A, B$ 成分のそれぞれの 重量分率，あるいはモル分率を $X_{A}, X_{B}$ とし，透過側

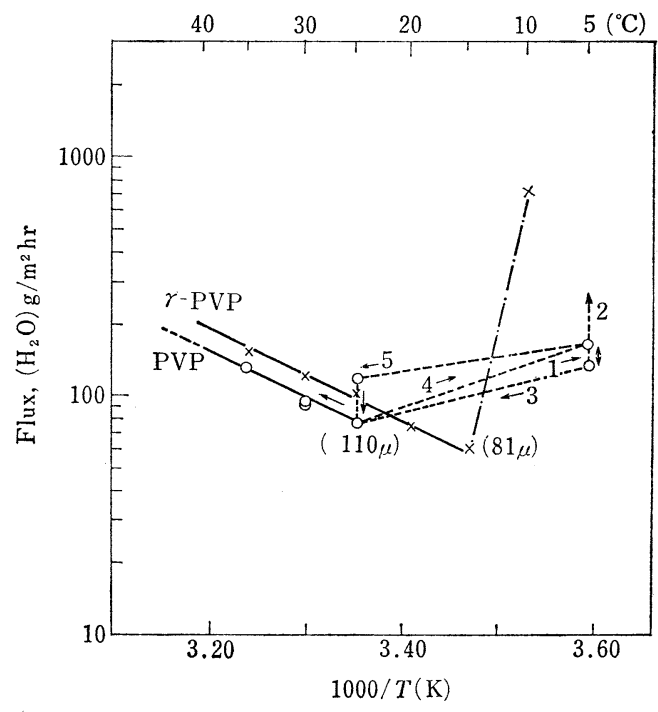

Fig. 15 ${ }^{21)}$ Semilog plots of water flux vs. reciprocal temperature: (O) PVP membrane $(110 \mu$ in thickness); (X) $30 \mathrm{Mrad}$ irradiated PVP membrane $(81 \mu)$.

（排気側）の $A ， B$ それぞれの重量分率，あるいはモル 分率を $Y_{A}, Y_{B}$ とすると, $A$ 成分に対する $B$ 成分の 分離係数は次のように表わされる.

$$
\alpha_{B A}=\frac{Y_{B} / Y_{A}}{X_{B} / X_{A}}=\frac{Y_{B}\left(1-X_{B}\right)}{X_{B}\left(1-Y_{B}\right)}
$$

次に多成分系の場合の分離係数を考えてみよう。例党 ば考えやすいように三成分系の構造異性体で，(1)オルト， (2)メタ，(3)パラの三つの成分からなる場合を取り上げて 考えてみると，まずオルトとパラの分離がうまくいって いるかという成分間同志の分離が問題になる。したがっ て (1) 式による $\alpha_{12}, \alpha_{23}, \alpha_{13}$ の三つの分離係数の表 わし方が考えられる，それとオルトならオルト化合物だ けが全体からどの程度分離されるかが次に問題になる。 この場合三成分系で，二成分系のときと同じ定義の記号 を suffix は別として使うと，オルト化合物(1)の全体に対 する分離係数 $\alpha_{1}$, Total は次のようになる.

$$
\alpha_{1, \text { Total }}=\frac{Y_{1} / Y_{1}+Y_{2}+Y_{3}}{X_{1} / X_{1}+X_{2}+X_{3}}=\frac{Y_{1} / \Sigma Y_{i}}{X_{1} / \Sigma X_{i}}
$$

ここで分離係数の予測值である透過速度比 (Permselectivity，PS $)^{6)}$ にも触れて打きたい，同一の分離膜に 対する $A, B$ 二つの透過物質に対する単独の透過速度を それぞれ， $Q_{A}, Q_{B}$ とし， 5 節で取扱 5 濃度平均拡散 係数を $\bar{D}_{A}, \bar{D}_{B}$, 溶解度を $C_{A}, C_{B}$ とすると, $A$ に対 する $B$ の透過速度比 $(P S)_{B / A}$ は次のように表わせる. 

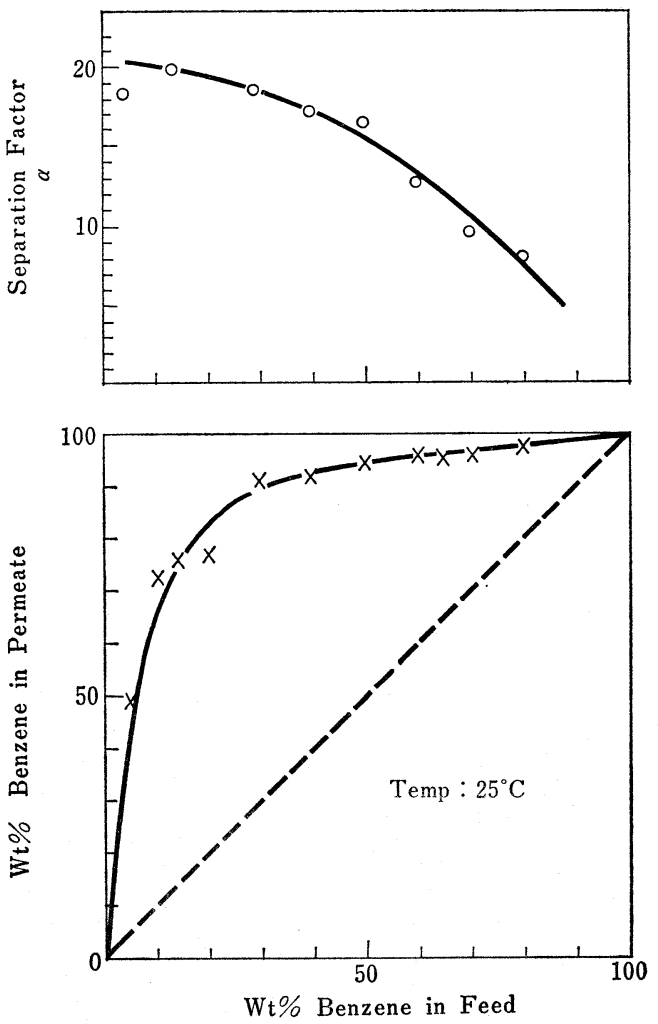

Fig. 1615) Effect of feed composition on the separation of benzene-aniline mixture at $25^{\circ} \mathrm{C}$.

$$
(P S)_{B / A}=Q_{B} / Q_{A}=\left(\bar{D}_{B} / \bar{D}_{A}\right)\left(C_{B} / C_{A}\right)
$$

現実には $(P S)$ と $\alpha$ とは違うが，目安なり，傾向な りをつかをえるには役立つ. $(P S)$ は結局, 溶解性の比と 濃度平均拡散係数の比の積で表わされるから, 分離性能 を上げるにはこのどちらかを改善するか，欲を言えば両 者を高めればよいことになる，溶解性は主に透過分子と 膜との分子間相互作用によって決まるものであり，一方 拡散の方は透過分子の形, 大きさまたは凝集状態によっ て決定される. したがって最も分離性をよくするために は, 供給液の各成分間の化学的性質と透過分子の形状が 大きく違っていなければならない。これは1960年代から 変わらぬ分離の指導原理である。

Fig. 16 に，架橋ポリエチレンフィルムによる分離で ベンゼンーアニリン系の混合液の組成を変えた場合, 透過 液の組成がどう変わるか, また分離係数がどう変化する かを図示した．この Fig. 16 は Fig. 15 と共に液透過分 離パラメータのデータを表示する図として非常に重要で

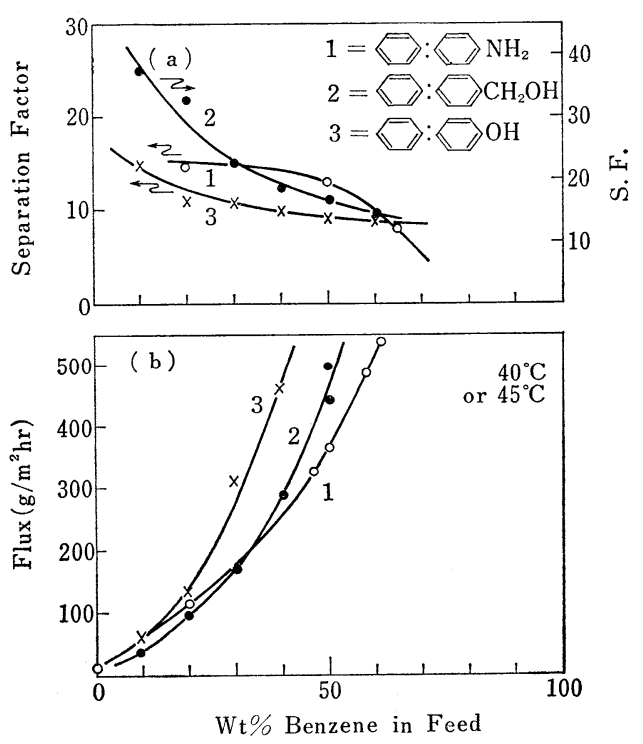

Fig. 1722) Liquid permeation rate and separation factor through $22 \mathrm{Mrad}$ irradiated polyethylene membrane for benzene-aniline, benzene-benzylalcohol and benzenephenol feed solution as a function of $\mathrm{Wt} \%$ of benzene: 1 . benzene-aniline at $45^{\circ} \mathrm{C} ; 2$. benzene-benzylalcohol at $40^{\circ} \mathrm{C}$; 3. benzene-phenol at $40^{\circ} \mathrm{C}$.

ある.Fig. 15 と Fig. 16 を一緒にまとめた図示の仕方も 行われている. Fig. 17 にはその1例を示した22). 特に Fig. 16 の下の, 供給液一透過液組成曲線の図からは, 分 離過程を分析して考えるとき，溶解で分けるか，拡散で 分けるかの一つの指針が得られる. Fig. 18 にとの解説図 をのせた ${ }^{13)}$ ．一般に膜中で溶媒の透過を支配する因子と して，先に述べたように膜表面への溶媒の溶解，および 膜中での溶媒の拡散が考えられる。したがって，混合物 の分離を行う場合に, 溶解の差を用いる場合と拡散の差 を用いる二通りの分離パターンが考えられる．溶解度の 差異を用いる場合には, 分離組成曲線の供給側の広い組 成範囲で，透過液組成が一定值に近づく．Fig. 18 に示 した曲線 $\mathrm{A}$ はこれを模式図的に示したもので，横軸およ び縦軸はそれぞれ供給液抏よび透過液中の特定成分の濃 度を表わしている.このような例としては，極性が異な る沸点近接混合物, および共沸混合物の分離があげられ る. 一方, 拡散の違いを用いる場合は, 分離係数が供 給側の広い組成範囲で一定に近い值をとることになる. 


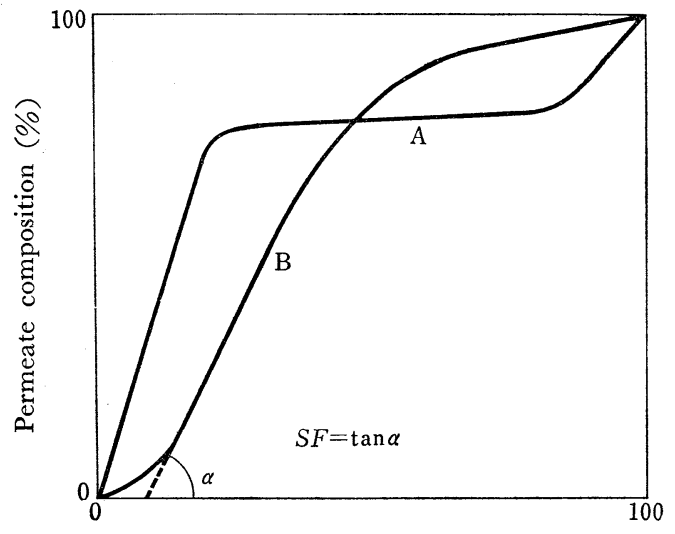

Feed composition (\%)

Fig. 1813) Separation pattern

Fig. 18 の図中で，分離係数は式（1）の定義から，勾 配として表わされるものである。すなわちこれはBの曲 線の場合に相当する。例えば異性体（例：パラ，メタ拉 よびオルトーキシレンなど）の分離がこれに属する。

以上のように, 液透過の場合膜性能の評価基準データ として最も重要なのは透過速度と分離係数の二つのパラ メータである，実際これに膜の耐久性を加えれば評価基 準の凡てであるといっても過言でない. しかしもう少し 細かく考察して, 膜の評価基準の観点から要求性能を⿱ とめてみると次のようになる.

(1)膜の分離生産性を上げるために透過速度が十分大き いこと. (2)目的の液成分に対し十分な選択分離性のある こと.このように目的とする成分を除去する場合，優先 的に透過させて除く場合と, 逆に通さないで取り除く場 合とが考えられる. (3)膜は操作条件において十分な耐久 性を持つこと.すなわら機械的性質が適当で, 面熱性, 耐溶剤性に優れており，膜が圧力でやぶれたり，高温下 で劣化したり，供給液で膜構造が破壊されたりしないで 長時間使用に耐えること. (4)膜の経時変化の少ないこと. 使用中に徐々に分離性能が劣化したりせず，保存がきく 膜素材であること.(5)膜厚が自由に調節できる製膜法が 存在すること.(6)均一性と再現性のある膜ができるこ と.すなわち膜面にピンホールやその他の欠陷が存在し ないこと.(7)均質な極薄のスキン層がつくられること. (8)出来れば大量生産が可能であり, 経済的に安価である こと、すなわち比較的簡単な工程で得られ，製膜が容易 であること. (9)与兄られた体積の中で大きな膜表面積が 得られるために, 中空糸膜に成形できることなどが実際 の液々分離膜の要求性能として考えられる. しかし, こ
Table 2 Effect of the swelling time on the liquid permeation rate $\left(\mathrm{g} / \mathrm{m}^{2} \cdot \mathrm{hr}, 25^{\circ} \mathrm{C}\right)$ of benzene ${ }^{24)}$

\begin{tabular}{llllllll}
\hline & \multicolumn{5}{c}{ Swelling time } \\
& & 1hr & 2hr & 1day & 2day & 10day \\
\hline Mode 1 & 349 & & & & & \\
Mode 2 & & 336 & 374 & 653 & 630 & 654 \\
\hline
\end{tabular}

Membrane: 22 Mrad irradiated PE

れらのなかには定量化できないものが多数含まれている し, 分離膜一般として共通する要求性能も入っている. さらに細かく論ずれば，4，5 で取扱ういろいろなパラ メータや数值も膜性能を判断する基準となる.

特に液透過の場合, 膜の分離性能の評価基準として最 も重要な分離係数 $(\alpha)$ と透過速度 $\left(\phi, \mathrm{kg} / \mathrm{m}^{2} \cdot \mathrm{hr}\right)$ との 総合的評価方法として，仲川23) はこの二つの数值の間 にほぼ逆数関係が成立することから, 二つの数值の積 $(\alpha \phi)$ を取り上げている。また液透過のチャンピオンデ 一タ (最高值) として， $\alpha \phi$ が 150 という值をあげてい る. 現在 $\alpha \phi$ の值として 15 程度のものは既にいくつか 得られている。

\section{3 パーベーパレーション測定法上の問題点}

3.1 の項で述べたように, 通常の実験では膜と供給液 が膨潤平衡に到達してから測定を開始するが，Table 2 に示したようにこの膨潤時間を変えた場合 (Mode 2) と, 膨潤時間を置かずにいきなり低圧側を減圧してから供給 液を与えた場合 (Mode 1) では, 明らかに透過速度が 異なる24). しかし Mode 1 と Mode 2 の測定法の違 いによる透過速度の相異は, 膨潤系でない場合には現わ れない，例えば $60^{\circ} \mathrm{C}$ に拈けるポリスチレン膜の透水 速度を測定すると Mode 1 と 2 による值はそれぞれ， 17 と $18 \mathrm{~g} / \mathrm{m}^{2} \cdot \mathrm{hr}$ であり誤差範囲で一致した ${ }^{24)}$.なおポ リエチレン膜に対するベンゼンーアニリン系のような膨 潤系の場合でも, 分離係数と液透過の活性化エネルギー は変わらなかった ${ }^{24)}$. いずれにしてもパーベーパレーシ ヨン法では膜の膨潤系を扱うために実験操作の手順に注 意する必要がある。

その他測定上の問題点としては，液透過実験では膜を 膨潤させやすい有機溶媒系を使うので何回も同一試料を 使うと膜構造が緩和されて, 液透過パラメータの数值が 変化してくることがある．このことは一言で言えば膜の 耐久性と関連し，再現性がそしいということにもなる。 
Table 36) Liquid permeation rate and selectivity as a function of film thickness Bakelite low-density polyethylene film ( $\rho=$ 0.9177 at $25^{\circ} \mathrm{C}$ )

Feed: $o$-xylene and $p$-xylene Permeate-zone pressure: $1 \mathrm{mmHg}$ Liquid charge temperature: $25^{\circ} \mathrm{C}$ $Q$,

\begin{tabular}{cccc}
\hline \multirow{2}{*}{$\begin{array}{c}\text { Film } \\
\text { thickness, } \\
\text { mils }\end{array}$} & $Q:\left(\frac{(\mathrm{lb} .)(\text { mil film thickness })}{(\mathrm{hr} .)\left(1000 \mathrm{ft.}{ }^{2}\right)}\right)$ & $\begin{array}{c}\text { Separation } \\
\text { factor, } \\
p \text {-xylene/ } \\
o \text {-xylene }\end{array}$ \\
\cline { 2 - 4 } 1 & 59.7 & 127.5 & 2.13 \\
2 & 64.2 & 131.2 & 2.04 \\
3 & 62.4 & 131.2 & 2.10 \\
\hline
\end{tabular}

\section{4. パーベーパレーション測定上に影響する因子}

パーベーパレーション実験を行う上で，透過分離パラ メータへの測定条件の影響を熟知して括くことは, 膜特 性を正当に評価するために必要なことである。そこで現 在までに明らかにされている範囲で透過分離パラメータ に影響を与える条件因子についてまとめた。

（1）透過速度は一般に膜の厚さの逆数に比例する。ま た膜の選択性は膜厚にはほとんど無関係である。

（2）透過速度と温度とはいわゆる Arrhenius の関係 にあるが，分離係数は殆んどの場合温度が上がると下が るのが普通である。

（3）混合液中の膨潤性の溶媒濃度の影響もほぼ温度と の関係と似ている.

（4）高圧側の圧力の増加は透過速度や分離性によい結 果をもたらさない。

（5）低圧側圧力の変化は透過速度や分離性にある程度 の影響を与えるが，ある圧力範囲ではほとんど無関係で あると考劣てよい。

（6）異方性の膜を使ったときには膜の向きによって透 過分離パラメータに違いが現われる.

（7）極性の違 う混合系の分離の場合は, 分離膜の極性 に近い成分がより多く選択的に透過し，分離されてくる。

（8）同族体間で比較した場合，透過物質の分子量が大 きくなるに従って透過速度は減少するが，分離性はよく なる，構造異性体では透過分子の断面積が大きい方が通 りにくい.

（9）結晶性の高分子膜では熱処理, あるいは溶剂処理 することで透過速度が数倍以上も増え，選択性がますこ

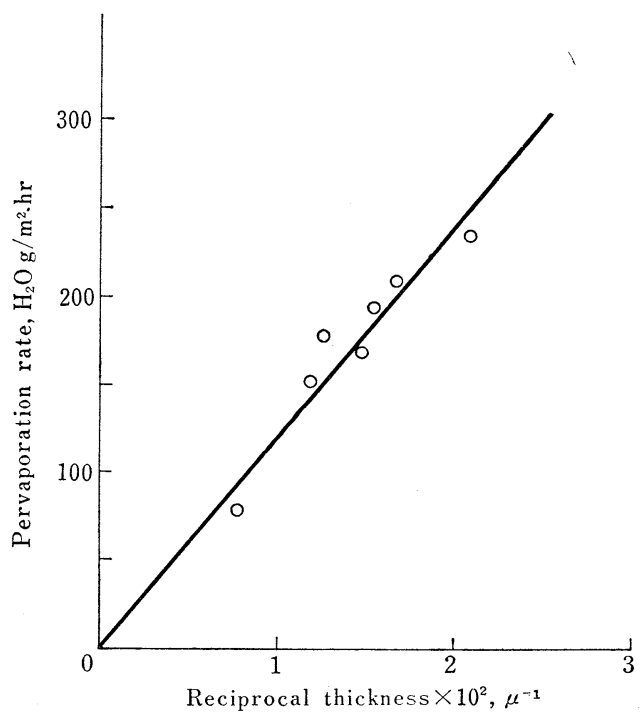

Fig. 1921) Effect of membrane thickness on pervaporation rate of water through PVP membranes at $25^{\circ} \mathrm{C}$.

とがある。

次にこれらの各項目について詳細に説明する.

(1) 膜厚の関係

比透過速度 $(R)$ は一般に膜の厚さに無関係な定数と して知られている，Rは 5 に述べる式 (5) から次のよ うに導かれる。

$$
R \equiv Q \cdot l=\int_{0}^{c_{1}} D(C) d c
$$

ここで $c_{1}$ は高濃度側の透過物質の濃度であるが，式 (4) から Q は厚さ $(l)$ に無関係なことが予想される. 3.2 に説明したように，膜の選択性はこの $Q$ の比であ ることから，したがって分離係数は膜厚に依存しないこ とがわかる (Table 3 参照)。また一定值をとるQは透 過速度と膜厚との積であるから，Fig. 19 のように透過 速度は膜の厚みに反比例することがわかる．結局厚さに よって分離機能は変わらないのだから, 膜の厚みは機械 的強度がもつ限り薄いにこしたことはない。

(2) 温度との関係

液透過の場合子他の膜透過の場合と同様に実験的には 透過速度と温度との間には Arrhenius の関係がなりた つ.ほとんどの液透過の条件では，気体透過と同じょう に，溶解一拡散過程で起きていると考えられるので，気 体透過の場合の温度との関係式が適用できる，透過速度 のみかけの活性化エネルギーはいくつか報告されている 
40 山田：液々透過膜の性能評価法

Table 415) Effect of temperature on the liquid permeation rate and the separation factor of benzene-aniline mixture $(1: 1$ $\mathrm{w} / \mathrm{w}$ )

\begin{tabular}{ccc}
\hline $\begin{array}{c}\text { Temp. } \\
\left({ }^{\circ} \mathrm{C}\right)\end{array}$ & $\begin{array}{c}\text { Flux } \\
\left(\mathrm{g} / \mathrm{m}^{2} \cdot \mathrm{hr}\right)\end{array}$ & $\begin{array}{c}\text { Separation } \\
\text { factor, } \alpha\end{array}$ \\
\hline 10 & 34.2 & 19.0 \\
25 & 86.5 & 17.2 \\
35 & 287.0 & 17.2 \\
45 & 587.0 & 13.3 \\
\hline
\end{tabular}

が，ガス透過の活性化エネルギーと対比させると数值的 にはほとんぞ変わらない．しかし透過物質の分子量を比 較した場合やや低く出るようである。透過速度と温度と は Arrhenius の関係があるが, selectivity に対して温度 は悪影響を及仿す。すなわち温度が上昇するにつれて， 透過速度は増大し (Fig. 15)， $\alpha$ は下がるのが一般的で めるが (Table 4)，必ずしもそうではなく， $\alpha$ がわずか に向上する例子報告されている (Fig. 20).

Fig. 15 はポリ-4ービニルピリジン (PVP) 膜と 30 Mrad $\gamma$ 線を照射して架橋した PVP 膜について, 水の 透過速度と温度の関係を調べたものであるが，ほ果きれ いな直線関係を示し, Arrhenius の関係が成立している. 二つの膜とも 8〜 $9 \mathrm{kcal} / \mathrm{mol}$ のみかけの活性化エネルギ 一を示した，パーベーパレーションの透過速度にも二次 転移点が現われることが報告されているが11)，他の膜分 離実験之違うことは透過物質の凝固点付近の温度まで泠 却すると異常現象が現われることである．Fig. 15 で例 学ば PVP 膜で $25^{\circ} \mathrm{C}$ から $5^{\circ} \mathrm{C}$ に冷やして透過速度を 測定すると，透過速度は逆に $25^{\circ} \mathrm{C}$ よりも上がり，この 温度でさらに時間が経過するとますます上昇する傾向が みられた。しかし，もら一度温度を $25^{\circ} \mathrm{C}$ にもどすと， 元の $25^{\circ} \mathrm{C}$ の数值より若干高い点に帰り,さらにある程 度この温度に放置してから透過速度を測定すると完全に 出発点にもどった。このような異常現象が起きるのは括 そらく膜の減圧側で，この場合水がいわば急激に断熱膨 張し，蒸発することになるので，その際水が膜面上で涷 結し，PVP 膜の微細構造を弛緩させるために透過速度 がふえるものと考劣られる。

（3）混合液中の膨潤性の溶媒の影響

Fig. 14 に示すように一般に膨潤性の成分をふやして いくと透過速度は exponential に増大するが，これは膜 が可塑化あるいは膨潤するためと考兄られる，分離係数 についても同様の効果があることは Fig. 16 亿示した。

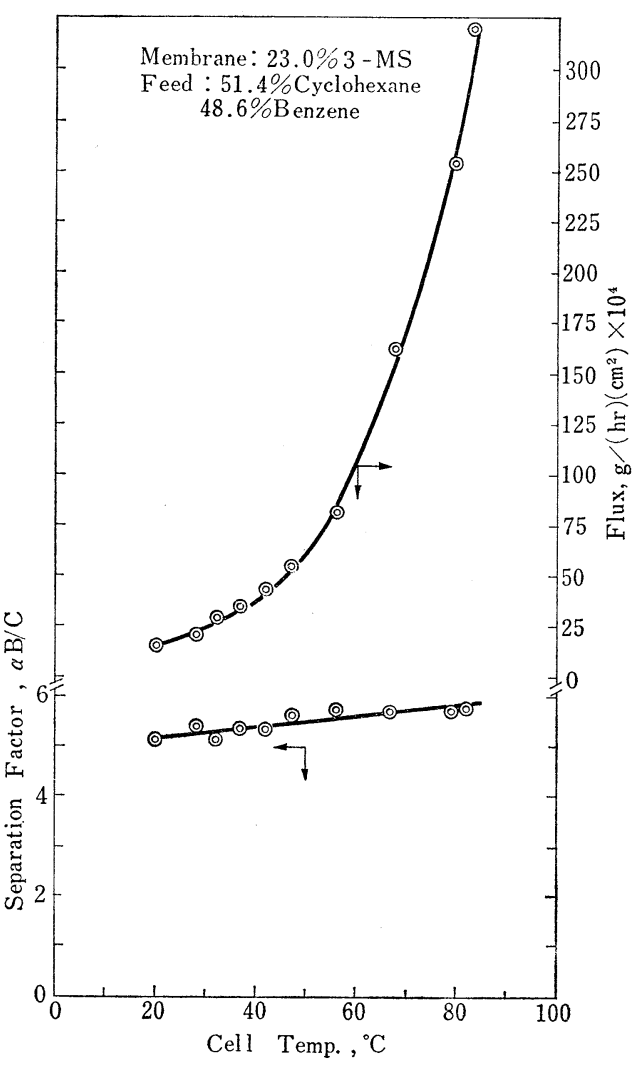

Fig. 2010) Effect of cell temperature on the separation of benzene and cyclohexane

(4) 圧力の影響

Table 5 に見られるように高圧側に圧力を印加すると， 透過速度は期待に反してやや落ちるが，分離係数は変わ らない. また低圧側の圧力をふやしていくと分離係数は, Table 6 でわかるように数 $10 \mathrm{mmHg}$ までの間ではほと んど変わらない，透過速度は低圧側圧力の増大と共にや や下がっていくが, 約 $100 \mathrm{mmHg}$ の圧力以上になると 一定值に落つくことが明らかにされている17). 詳細に検 討すると Fig. 21 に示すように低圧側の圧力が上るに 従ってある範囲までは分離率がよくなることがわかる17)

（5）異方性膜の方向性

まずポリエチレン膜の片面のごく表面を光塩素化させ， さらにエチレンジアミンと反応させることによって，片 面だけにアミノ基を保持させたポリエチレン膜を得た． この改質膜のエチレンジアミン反応層を, 高濃度側にさ けたときと低濃度側に 向けたときのベンゼンーアニリン 混合液の分離結果を Fig. 22 にのせた。明らかに膜の 
Table 59) Effect of upstream pressure on pervaporation data

\begin{tabular}{ccc}
\hline Upstream pressure, bar & Pervaporation rate $\phi, \mathrm{kg} / \mathrm{hr}-\mathrm{m}^{2}$ & Selectivity $\alpha$ \\
\hline 1 & 0.37 & 16 \\
5 & 0.28 & 16 \\
10 & 0.24 & 16 \\
\hline
\end{tabular}

a Liquid charge mixture, water $(50 \mathrm{~m} l)$ plus $\mathrm{N}$, N-dimethylformamide $(50 \mathrm{~m} l)$; membrane, PTFE-P4VP 21 $\%$ grafting; PTFE thickness, $50 \mu$; temperature, $20^{\circ} \mathrm{C}$; downstream pressure, $10^{-2} \mathrm{mmHg}$.

Table 69) Effect of downstream vapor pressure on pervaporation data

\begin{tabular}{cccc}
\hline $\begin{array}{c}\text { Condensation temp. of } \\
\text { pervaporate }{ }^{\circ} \mathrm{C}\end{array}$ & $\begin{array}{c}\text { Downstream pressure of } \\
\text { pervaporate, } \mathrm{mmHg}\end{array}$ & $\begin{array}{c}\text { Pervaporation rate } \\
\phi, \mathrm{kg} / \mathrm{hr}-\mathrm{m}^{2}\end{array}$ & Selectivity $\alpha$ \\
\hline Liquid air & 0.01 & 4.1 & 3.3 \\
-10 & 38 & 4.0 & 2.8 \\
0 & 70 & 3.7 & 2.4 \\
+10 & 110 & 2.8 & 2.1 \\
\hline
\end{tabular}

a Liquid charge mixture, methyl alcohol (20g) plus methyl acetate $(80 \mathrm{~g})$; membrane, PTFE-PVP 70\% grafting; PTFE thickness, $50 \mu$; temperature, $27^{\circ} \mathrm{C}$.

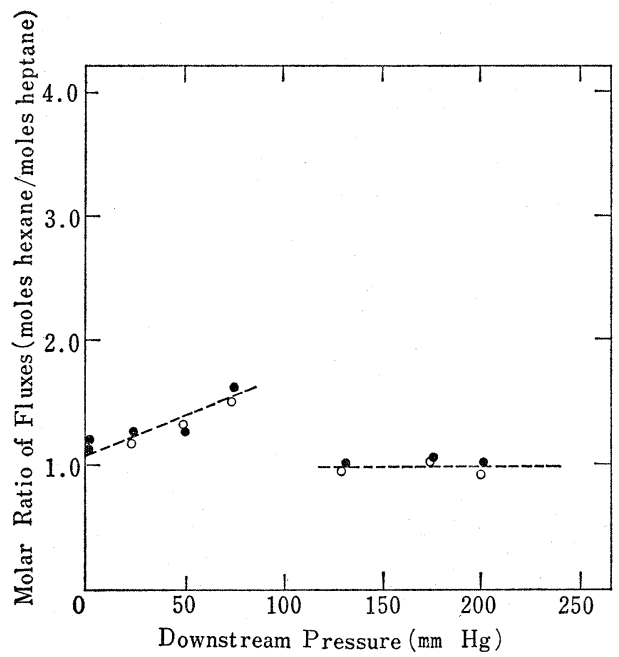

Fig. 2117) Molar ratio of fluxes (hexane to heptane) vs. downstream pressure for two values of upstream pressure: 11.2 atm. (0.5 mole fraction hexane in the permeant charged); and $\bigcirc, 21.4 \mathrm{~atm}$. (0.53 mole fraction hexane in the permeant charged).
反応層が活性層として働くときには, 分離係数の control 膜に対する違いはでてくるが，膜を反対の向きに置いた ときには分離係数は control と全く重なってしまう。こ のように異方性膜の場合は膜の方向性に強く依存する.

(6) 極性の違い

Table 7, Fig. 17 と 22 に示すように同じような分子 形や大きさのものでも, 極性の違いによって透過速度と 分離係数がちがうことは明らかである.

(7) 同族体の分離

次に膜との化学的親和性の違いがほとんど見られない 同族体の分離をとりあげる. Table 8 には分子形の同じ キシレンの構造異性体の透過速度の比較をしたが, 分子 容が等しく，長軸長と長軸方向分子断面積の異なる場合 は長軸方向分子断面積によって流速が決定されることが 読みとれる。

Table 9 は枝分れ等の異なる脂肪族系の構造異性体の 例であるが，同じように長軸方向分子断面積との相関が ある. 次に分子断面積を一定にして, 分子の大きさを変 えた場合をTable 10 に示したが,この場合分子の大きさ のみに依存していることが明らかであるう．しかし流速 に対する分子の形状と大きさの影響と化学的親和性の影 響とを対比させた場合，一般的には後者の影響が大きい。

（8）熱処理と溶剤処理

Michaels ら ${ }^{16)}$ はポリエチレンとポリプロピレンの結 
Table 76) Liquid permeation rate as a function of chemical nature 1-mil polyethylene film $\left(\rho=0.922\right.$ at $70^{\circ} \mathrm{F}$.) Permeation temperature: $100^{\circ} \mathrm{F}$.

\begin{tabular}{lcccc}
\hline \multicolumn{1}{c}{ Permeant } & Molar volume, cc./mole & $\bar{V} / \bar{L}$ & $\begin{array}{c}\text { Solubility parameter, } \\
\delta, \text { at } 25^{\circ} \mathrm{C} .\end{array}$ & $Q,\left(\frac{(\text { lb. })(\text { mil thickness) }}{(\mathrm{hr} .)\left(1000 \mathrm{ft} .{ }^{2}\right)}\right)$ \\
\hline Benzene & 89 & 12.7 & 9.2 & 209 \\
Butyraldehyde & 88 & 10.4 & 9.6 & 8.7 \\
Phenol & 88 & 10.3 & 12.1 & 0.43 \\
\hline
\end{tabular}
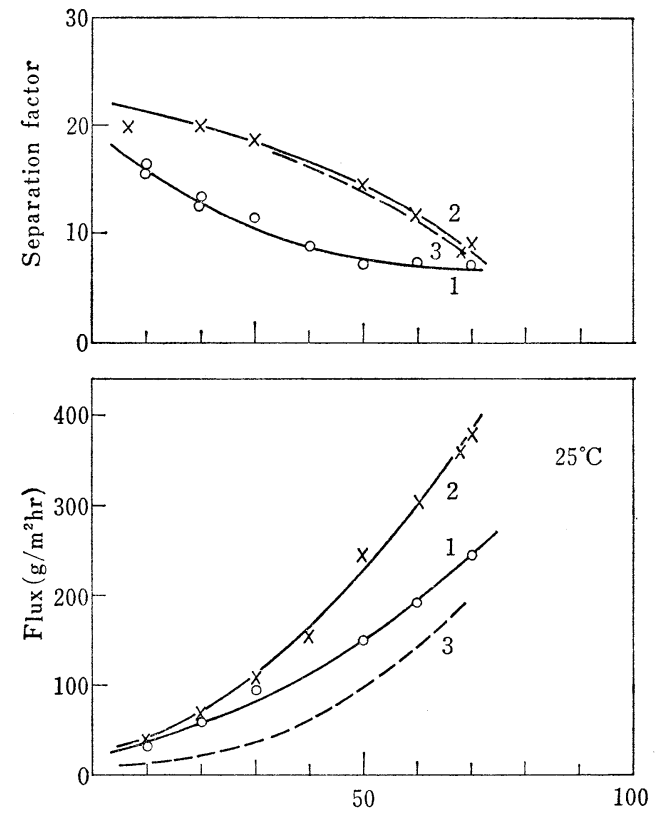

Wt $\%$ Benzene in Feed

Fig. 2222) Liquid Permeation rate and separation factor through $22 \mathrm{Mrad}$ irradiated polyethylene membrane and ethylenediamine reacted polyethylene membrane as a function of wt \% of benzene in benzene-benzylalcohol feed solution at $25^{\circ} \mathrm{C}$.

..... : 22 Mard irradiated polyethylene membrane;

_- : Ethylenediamine reacted polyethylene membrane

1. Reacted layer corresponds to active layer

2. Reacted layer does not correspond to layer

3. Control PE

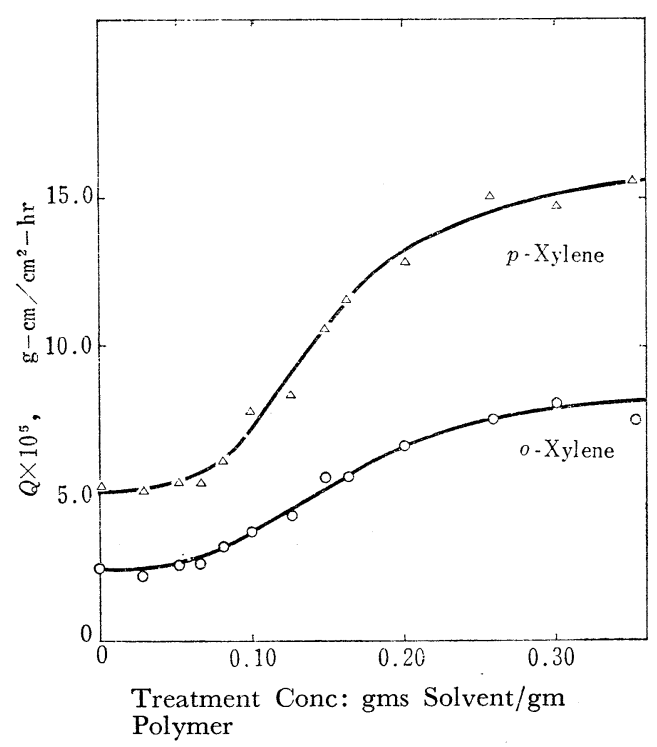

Fig. 2316) Permeation flux vs. treatment concentration for $p$ - and $o$-xylene at $30^{\circ} \mathrm{C}$. Polymer treated with $p$-xylene at $97^{\circ} \mathrm{C}$.

晶性ポリマーによるキシレン異性体の液分離を検討し， その透過性能がキシレン異性体による溶剂処理と熱処理 によって変化することを見出した，すなわち膜の結晶性 領域と非結晶性領域との間で形成される sieve の鋳型が 溶剤処理や熱処理によって変わり，分離にとって望まし い方向に改質されることがはっきりした．Fig. 23 はポ リエチレン膜を溶媒で preswell したときの透過速度へ の効果を示す．このことは逆に液分離用の膜が耐久性に 劣り, 再現性にそしいことにも関連してくる.

\section{5. 数学的取扱い}

まず混合液体でなく単一成分の透過の場合を考えてみ 上5。透過速度（Q）は Fick の第一法則によって次の 
Table 86) Liquid permeation rates as a function of molecular shape

Grex linear polyethylene film $\left(\rho=0.9570\right.$ at $25^{\circ} \mathrm{C}$. $)$

Feed: xylene isomers

Permeate-zone pressure: $1 \mathrm{mmHg}$

Liquid charge temperature: $50^{\circ} \mathrm{C}$.

\begin{tabular}{lcccc}
\hline Permeant & $\bar{V}$, cc. $/$ mole at $20^{\circ} \mathrm{C}$. & $\bar{L}, \mathrm{~cm}$. & $\bar{V} / \bar{L}$ & $Q,\left(\frac{\text { (lb.) (mil film thickness) }}{(\mathrm{hr} .)\left(1000 \mathrm{ft} .{ }^{2}\right)}\right)$ \\
\hline$o$-Xylene & 121 & 8.7 & 13.9 & 57.6 \\
$m$-Xylene & 123 & 9.3 & 13.2 & 79.3 \\
$p$-Xylene & 124 & 9.7 & 12.8 & 101 \\
\hline
\end{tabular}

Table 96) Liquid permeation rate as a function of molecular shape 0.0046-cm. polymeric film

Feed: hexane isomers

Permeate-zone pressure: $360 \mathrm{~mm}$. Hg

Liquid charge temperature: $50^{\circ} \mathrm{C}$

\begin{tabular}{lcccc}
\hline Permeant & $\bar{V}$, cc./mole at $20^{\circ} \mathrm{C}$. & $\bar{L}, \mathrm{~cm}$. & $\bar{V} / \bar{L}$ & $Q,\left(\frac{(\text { lb. })(\text { mil film thickness) }}{(\mathrm{hr} .)\left(1000 \mathrm{ft} .{ }^{2}\right)}\right)$ \\
\hline$n$-Hexane & 131 & 10.85 & 12.1 & 68.7 \\
Iso-hexane & 132 & 9.50 & 13.9 & 20.7 \\
Neohexane & 133 & 8.15 & 16.3 & 0.71 \\
\hline
\end{tabular}

Table 10 Liquid permeation rate as a function of molecular size 1-Mil polyethylene film $\left(\rho=0.922\right.$ at $70^{\circ} \mathrm{F}$.)

Liquid permeation temperature: $70^{\circ} \mathrm{F}$.

\begin{tabular}{lcccc}
\hline Permeant & $\bar{V}$ cc./mole at $20^{\circ} \mathrm{C}$. & $\bar{L}, \mathrm{~cm}$. & $\bar{V} / \bar{L}$ & $Q,\left(\frac{(\mathrm{lb} .)(\mathrm{mil} \text { film thickness })}{(\mathrm{hr} .)\left(1000 \mathrm{ft} .{ }^{2}\right)}\right)$ \\
\hline$n$-Pentane & 115.2 & 9.5 & 12.0 & 69.5 \\
$n$-Heptane & 146.5 & 12.2 & 12.1 & 35.6 \\
$n$-Decane & 194.0 & 16.2 & 12.0 & 9.4 \\
$n$-Tetradecane & 259.0 & 21.6 & 12.0 & 2.1 \\
\hline
\end{tabular}

ように表わされる。

$$
Q=-D(C) \frac{d c}{d x}
$$

ここで, $c$ は高分子膜中の 溶媒分子の濃度で, $x$ は供 給液側から測った膜中の長さ, これから Fick の第二法 則は次のようになる。

$$
\frac{d}{d x} D(C)-\frac{d c}{d x}=0
$$

この $D(C)$ の最も一般的に使われる表現は， $c$ に対す
る一次式や二次式でなく，対数的な関係で表わされるこ とが多い. Barrer は膜中の透過物質の濃度に依存する 場合の拡散係数は次のように表現できるとした。

$$
D(C)=D_{0} \exp (a C)
$$

ここで $D_{0}$ は濃度零のとさの拡散係数, $a$ は透過物質 の可塑化作用の一つの目安として表わされる定数である. この二つのパラメータは温度, 結晶性, 膜素材と溶媒分 子との物理的，化学的性質の関係などによって決定され るものである. 
44 山田：液々透過膜の性能評価法

（7）式を（6）式に代大し, 境界条件を入れて積分す ると, ここで $x=0$ で $C=C_{1}, x=l$ で $C=C_{2}$ とすれ ば,

$$
Q=\frac{D_{0}}{a l}\left(\exp a C_{1}-\exp a C_{2}\right)
$$

が得られる。すなわち. Fig. 14 にみられるように透過 速度は溶媒の膜中濃度と対数関係にある. また膜中の濃 度分布は次のようになる。

$$
C=\frac{1}{a} \ln \left[\exp a C_{1}-\frac{x}{l}\left(\exp a C_{1}-\exp a C_{2}\right)\right]
$$

今膜の境界での濃度はある熱力学的な平衡が成り立つ ஓのと考えて,

$$
C_{1}=C *\left(P^{\circ}\right), \quad C_{2}=C *\left(P_{2}\right)
$$

で表わす．C*は関数関係を示すもので， $P^{\circ}$ は実験温度 での液の飽和蒸気圧， $P_{2}$ は低圧側の蒸気圧である。こ の式を使えば（8)，（9）式は $P^{\circ}$ と $P_{2}$ で表現される はずである。一方透過率 $\bar{P}$ は次のように誘導される.

$$
\begin{aligned}
& \quad \vec{P}=\frac{Q l}{\Delta P}=\frac{D_{0}}{a \cdot \Delta P}\left(\exp a C_{1}-\exp a C_{2}\right) \\
& \text { ここで } \quad \Delta P=P^{\circ}-P_{2}
\end{aligned}
$$

(10) 式に戻って, この場合 $C *(P)=S \cdot P$ なる Henry の法則がなりたつと考劣ると，（8），（9），(11）式は いずれも $P^{\circ}$ と $P_{2}$ の関数として次式のように表わされ る.

$$
\begin{aligned}
& Q=\frac{D_{0}}{a l}\left(\exp a S P^{\circ}-\exp a S P_{2}\right) \\
& C=\frac{1}{a} \ln \left[\exp a S P^{\circ}-\frac{x}{l}\left(\exp a S P^{\circ}-\exp a S P_{2}\right)\right] \\
& \bar{P}=\frac{D_{0}}{a \Delta P}\left(\exp a S P^{\circ}-\exp a S P_{2}\right)
\end{aligned}
$$

これらの式はいずれも実験的に証明されている.

パーベーパレーション液分離では, ガス透過で取扱わ れるように透過係数を溶解度係数と拡散係数とに分離し て考察するようなことは, 理論的にも実験的にも無理で ある. そうかといって逆浸透法で扱われているような現 象論的な定数を定めて論議することもない，たたここで 注意したいのは, 実際の液透過実験で得られる透過量は みかけのもので, それを $Q_{i}{ }^{l}$ とすると気体透過の場合 とは違って, 真の透過量 $\left(Q_{i}\right)$ は境界領域の効果を差し 引かなければ得られない，特に膜型人工肺における血液 境膜係数は単なる物理的な場合よりも $2 \sim 3$ 倍大きいこ とが知られている，そこで溶液相と蒸気相での $i$ 成分 の透過液の境膜抵抗をとれぞれ $r_{i}{ }^{l}$ と $r_{i}{ }^{v}$ とし, 膜厚 をしとすると，

$$
\frac{1}{Q_{i}{ }^{l}}=\frac{\left(r_{i}{ }^{l}+r_{i}{ }^{v}\right)}{l}+\frac{1}{Q_{i}}
$$

という関係が得られる。しかしパーベーパレーションの 場合一般的にはこの効果は無視されている.

次に, 膜透過分離挙動を解析する手法としての透過比 $(\Theta$, permeation ratio) の考方方を紹介してみよう.

$$
\Theta=Q / Q^{\circ}
$$

$Q$ は混合液の場合の実際の全透過速度, $Q^{\circ}$ は各成分 の透過速度から推定した混合液の全透過速度である。そ れぞれの成分の透過比 $\left(\theta_{i}\right)$ も，A，B 2 成分系として 考えると，次のように定義される.

$$
\theta_{A}=q_{A} / q_{A}^{\circ}, \theta_{B}=q_{B} / q_{B}^{\circ}
$$

$q_{i}, q_{i}^{\circ}$ はそれぞれの成分の $Q, Q^{\circ}$ に相当するもの である。これらの式からもわかるように，系が成分間の 相互作用のない理想的な挙動を示す場合であれば $\Theta$ は 1 になる。しかし一般には 1 より大きいか，小さいかで めり，もし1より大きいときを考えるとこの系は透過速 度を増大させる効果がある場合であり，逆に小さくなる と理想的な透過速度より却制する働きがあることになる。

Fig. 24 にセロハン膜で diethylamine-water の混合系 を分離する場合，このようなことが起こっていることを 示した25).

ジエチルアミンの場合は $\theta_{i}$ が 1 より相当大きい值を 示しているが，水は逆に1より小さくなっている，この ように透過比の考学を入れて図解してみると，混合系に したときの成分の透過速度がどのように変化しているか が明らかになる。一般に通りやすい成分と通りにくい成 分との混合では, 通りやすいものは単独のときょり通り にくくなり，通りにくいものは通りやすくなるという傾 向がみられる。

このような関係を簡単な数式処理してみよう。まず膜 を通しての全体の透過速度 $Q$ は， $A ， B$ の二成分系で は次式のようにそれぞれの成分の透過速度の和となる。

$$
Q=q_{A}+q_{B}
$$

いまかりにこの膜透過が理想状態，すなわち被分離液 が相互の透過過程に作用を及隹しあわないとすると，混 合液での各成分の透過速度はつぎのように表わされるは ずである。

$$
q_{A}=X_{A} \cdot q_{A}^{\circ}, q_{B}=X_{B} \cdot q_{B}^{\circ}
$$

$X_{A}, X_{B}$ はそれぞれ $A, B$ 成分の重量分率である. つぎに，理想的な系においては全透過速度 $Q^{\circ}$ は，

$$
Q^{\circ}=X_{A} \cdot q_{A}{ }^{\circ}+\left(1-X_{A}\right) q_{B}{ }^{\circ}
$$

となる. またこの系での分離係数 $\alpha^{\circ}{ }_{B / A}$ は, $q_{B} / q_{A}=$ $Y_{B} / Y_{A}$ であるから次のように表わされる. 


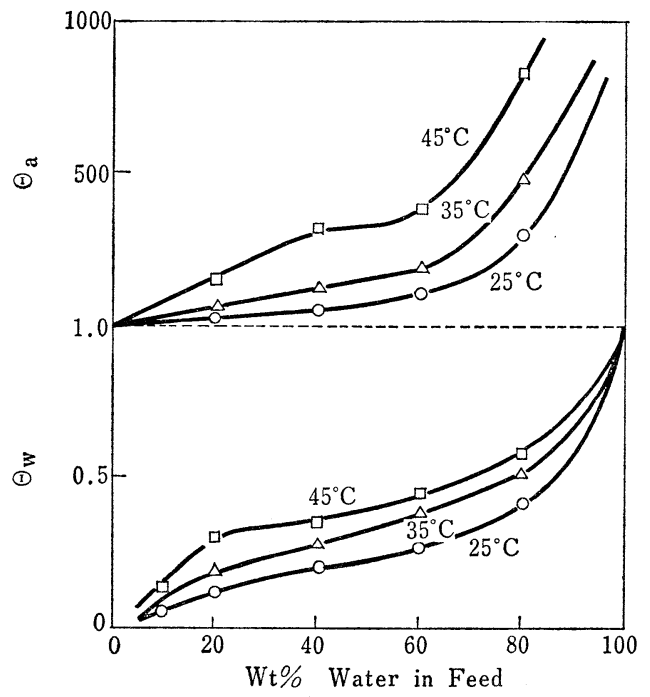

Fig. 2425) Effect of feed composition on the permeation ratio of diethylamine-water mixture.

$$
\begin{aligned}
\alpha_{B / A} & =\frac{Y_{B} / Y_{A}}{X_{B} / X_{A}}=\frac{q_{B} / q_{A}}{X_{B} / X_{A}} \\
& =\frac{X_{B} \cdot q_{B}^{\circ}}{X_{A} \cdot q_{A}^{\circ}} \cdot \frac{X_{A}}{X_{B}}=\frac{q_{B}^{\circ}}{q_{A}^{\circ}}
\end{aligned}
$$

最後に, 浸透気化過程においても気体透過と同じょう に, 透過率 $\bar{P}$ は擬溶解度係数 $K_{1}$ と濃度平均拡散係数 $\bar{D}$ の積で表わされることを誘導して扰こう。

（5）式を積分すると,

$$
\begin{aligned}
Q \cdot l & =-\int_{c_{1}}^{c_{2}} D(C) d c \\
\text { ここで } \quad Q & =\bar{P}\left(P_{1}-P_{2}\right) / l
\end{aligned}
$$

$P_{1}, P_{2}$ は膜中のそれぞれ高濃度側と低濃度側の蒸気 圧である。

したがって式 (22) と（23）から

$$
\bar{P}=\left[\int_{c_{2}}^{c_{1}} D(C) d c\right] /\left(P_{1}-P_{2}\right)
$$

(23) 式へ（24）式を代入すると,

$$
Q l \equiv R=\bar{P}\left(P_{1}-P_{2}\right)=\int_{c_{2}}^{c_{1}} D(C) d c
$$

ここで濃度平均拡散係数 $\bar{D}$ を次のように定義する.

$$
\bar{D} \equiv\left(\int_{c_{2}}^{c_{1}} D(C) d c\right) /\left(C_{1}-C_{2}\right)
$$

（20）式で $\bar{D}$ はもし拡散が透過物質の濃度に依存し
ないならば，普通の拡散係数 $D$ と全く等しくなる.

（26）式を（25）式に代入することによって,

$$
\begin{aligned}
& R=\bar{D}\left(C_{1}-C_{2}\right) \\
& \bar{P}=\bar{D}\left[\left(C_{1}-C_{2}\right) /\left(P_{1}-P_{2}\right)\right]
\end{aligned}
$$

多くの場合 $P_{1} \gg P_{2}$ であるから, 式 (26), (27),

（28）は次のように省略できる.

$$
\begin{aligned}
& \bar{D}=\left(\int_{0}^{c_{1}} D(C) d c\right) / C_{1} \\
& R=\bar{D} C_{1} \\
& \bar{P} \equiv \bar{D}\left(C_{1} / P_{1}\right) \\
& \text { ここで } C_{1} / P_{1} \text { を } K_{1} \text { と置くと, } \\
& \bar{P}=\bar{D} \cdot K_{1}
\end{aligned}
$$

となる。 $K_{1}$ は膜中の高濃度側に打ける透過物質の提 溶解度係数といわれるもので, 濃度依存性がある。結論 としていえることは, 透過率 $\bar{P}$ は濃度平均拡散係数 $\bar{D}$ と傕溶解度係数 $K_{1}$ との相乗積で表わされ, また比透 過速度 $R$ は濃度平均抎散係数 $\bar{D}$ と膜中の高濃度側の 濃度 $C_{1}$ との積となる.

\section{文献}

1) L. Kahlenberg: J. Phys. Chem., 10, 141 (1906)

2) K. Kammermeyer, D. H. Hagerbaumer: A. I. Ch. E. J., 1, 215 (1955)

3) E. G. Heisler, A. S. Hunter, J. Siciliano, R. M. Treadway: Science, 124, 77 (1956)

4) R. C. Binning, F. E. James: Petr. Refiner, 39, 214 (1958); R. C. Binning, R. J. Lee, J. F. Jennings, E. C. Martin: Ind. Eng. Chem., 53, 45 (1961)

5) A. S. Michaels, R. F. Baddour, H. J. Bixler, C. Y. Choo: Ind. Eng. Chem. Process Design Develop., 1, 14 (1962)

6) C. Y. Choo: "Membrane Permeation in Advances in Petrol. Chem. and Refining", ed. by Mcketta, Vol. 6, Interscience, N. Y. (1962)

7) N. N. Li, E. J. Henley: A. I. Ch. E. J., 10, 666 (1964); N. N. Li, R. B. Long: ibid., 15, 73 (1969)

8) I. Cabasso, J. Jagur-Grodzinski, D. Vofsi: J. Appl. Polym. Sci., 18, 2117, 2137 (1974)

9) P. Aptel, J. Cuny, J. Jozefowicz, G. Morel, J. Neel: J. Appl. Polym. Sci., 16, 1061 (1972); 18, 351, 365 (1974); P. Aptel, N. Challard, J. Cuny, J. Neel: J. Memb. Sci., 1 (1976) 271

10) F. P. McCandless: Ind. Eng. Chem. Process Des. Develop., 12(3) 354 (1973); J. G. Sikonia, F. P. McCandless: J. Memb. Sci., 4 (1978) 229

11) Sun-Tak Huang, Karl Kammermeyer: "Membranes in Separation, Techniques of Chemistry Vol. II," Wiley-Interscience (1975)

12）山田純男：工業材料，23(3)，51 (1975) 
46 山田 : 液々透過膜の性能評価法

13) 原 重義, 森 興: 「高分子の構造と分離機能」, 高橋 彰, 滝沢 章, 山下雄也共編: p. 109, 化学 同人 (1976)

14) D. R. Paul, O. M. Ebra-Lima: J. Appl. Polym. Sci., 14, 2201 (1970)

15) 山田純男, 浜谷健生：高分子論文集, 33, 217 (1976)

16) R. F. Baddour, A. S. Michaels, H. J. Bixler, R. P. DeFilippi, J. A. Barrie: J. Appl. Polym. Sci., 8, 897 (1964)

17) F. W. Greenlaw, W. D. Prince, R. A. Shelden, E. V. Thompson: J. Memb. Sci., 2 (1977) 141; F. W. Greenlaw, R. A. Shelden, E. V. Thompson:
J. Memb. Sci., 2 (1977) 333

18) 吉增史朗, 野村 仁, 小宮強介, 岡野光夫, 篠原 功：日化, 1980 (11) 1785

19)山田純男, 田口和宏, 浜谷健生: 特許出願中

20）鈴木文男, 小野里健二, 高橋直通, 日化化学系協会 連合東北地方大会予稿集，p. 53 (1972)

21) 山田純男, 浜谷健生: 高分子論文集, 投稿中

22) S. Yamada, T. Hamaya: J. Memb. Sci., in preparation

23）仲川 勤: 表面, 18(9), 475 (1980)

24) 山田純男, 浜谷健生：高分子論文集, 投稿中

25) 浜谷健生, 山田純男 : 高分子論文集, 37, 65 (1980) 